\title{
IS COMMONALITY IN LIQUIDITY A PRICED RISK FACTOR?
}

\author{
CLÁUDIO P. SILVA JÚNIOR ${ }^{1}$ \\ (iD https://orcid.org/0000-0002-3665-7077 \\ MÁRCIO A. V. MACHADO \\ (iD) https://orcid.org/0000-0003-2635-5240
}

To cite this paper: Silva Júnior, C. P., \& Machado, M. A. V. (2020). Is commonality in liquidity a priced risk factor? Revista de Administração Mackenzie, 21(2), 1-27. doi:10.1590/1678-6971/ eRAMF200158

Submission: Oct. 19, 2018. Acceptance: Aug. 9, 2019.

Universidade Federal da Paraíba (UFPB), João Pessoa, PB, Brazil.

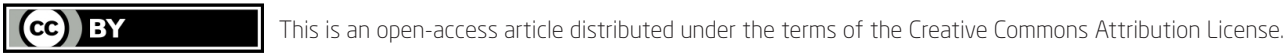

\footnotetext{
This paper may be copied, distributed, displayed, transmitted or adapted if provided, in a clear and explicit way, the name of the journal, the edition, the year and the pages on which the paper was originally published, but not suggesting that RAM endorses paper reuse. This licensing term should be made explicit in cases of reuse or distribution to third parties. It is not allowed the use for commercial purposes.

Este artigo pode ser copiado, distribuído, exibido, transmitido ou adaptado desde que citados, de forma clara e explícita, o nome da revista, a edição, o ano e as páginas nas quais o artigo foi publicado originalmente, mas sem sugerir que a RAM endosse a reutilização do artigo. Esse termo de licenciamento deve ser explicitado para os casos de reutilização ou distribuição para terceiros. Não é permitido o uso para fins comerciais.
} 


\section{ABSTRACT}

Purpose: Analyze if the commonality in liquidity is priced and its relation with the stock return in the Brazilian stock market.

Originality/value: Due to the shortage of papers about the effects of commonality in liquidity in the Brazilian financial literature, this paper provides knowledge development about commonality in liquidity effect for the investor, investigating whether an investment strategy in the most sensitive assets to systematic variations of liquidity is attractive for investors, consistent with the risk-return trade off.

Design/methodology/approach: In order to identify the effect of commonality to investors, we opted to use portfolios. Using companies listed on B3 as a sample, we estimated regressions developed in the time series from January 2007 to December 2015.

Findings: We found that the commonality is a phenomenon present in the Brazilian stock market and their highest values were concentrated in periods of international financial crises. In addition, using portfolios, we observed a premium of $4.165 \%$ per month for the commonality in liquidity, although not statistically significant. Finally, we found that the commonality in liquidity is a priced risk factor and when we exposed it to other risk factors we found that the liquidity risk factor was able to partly capture it.

\section{KEYWORDS}

Commonality. Investment. Liquidity. Risk. Return. 


\section{INTRODUCTION}

One of the main changes in global financial markets over the past 20 years has been the growth in the aggregate stock market trading volume (Foran, Hutchinson, \& O'Sullivan, 2015). As a consequence, with the many market crises and because of several cases of shortage of liquidity they bring about (Mayordomo, Rodriguez-Moreno, \& Peña, 2014), the role of liquidity has gained attention (Sadka, 2011).

The financial literature on liquidity currently considers the following possible relations across four different variables: firm return, $R_{i}$, firm liquidity, $L_{i}$, market return, $R_{m}$, and market liquidity, $L_{m}$ (Sadka, 2011). On a covariance matrix reflecting the interaction of such four variables, Sadka (2011) demonstrates the possible fields of liquidity studies: the study of liquidity volatility,

the study of stock liquidity risk pricing, $\operatorname{cov}\left(R_{i}, L_{m}\right)$; and systematic liquidity variations, $\operatorname{cov}\left(L_{i}, L_{m}\right)$.

The extent to which liquidity shows systematic variations, $\operatorname{cov}\left(L_{i}, L_{m}\right)$, which is the object of this study, was primarily documented by Chordia, Roll and Subrahmanyam (2000); up to the early 2000s there were no theoretical or empirical works that analyzed the covariance between systematic liquidity and stock liquidity (Brockman \& Chung, 2002).

Chordia et al. (2000) were the precursors of this line of research and demonstrated that liquidity, transaction costs and other individual characteristics of stocks had common determinants, and named them commonality in liquidity. In their definition, Chordia et al. (2000) characterized commonality in liquidity as the covariation between individual stock liquidity and market and industry liquidity, thus, resulting in commonality in liquidity risk, that is, variations in stock liquidity are determined also by systematic factors.

Therefore, commonality in liquidity may represent a non-diversifiable priced risk source, which may affect asset prices if investors demand a higher expected return of stocks with higher sensitivities to market liquidity shocks (Chordia et al., 2000).

More intuitively, just like the correlation among stocks is important for the variance of a portfolio, commonality in liquidity becomes important for the expected transaction cost, considering that stocks that are more likely to become illiquid during market declines will have higher transaction costs (Anderson, Binner, Hagströmer, \& Nilsson, 2016). 
Based on this, investors must be more attentive to the variance in liquidity due to systematic factors, considering that it is a non-diversifiable risk source and cases of reduced market liquidity occur when investors need urgent liquidity (Qian, Tam, \& Zhang, 2014). Then, investors must demand a higher return rate to purchase stocks whose liquidity is more sensitive to systematic liquidity.

A substantial literature has documented the existence of commonality in liquidity (Hasbrouck \& Seppi, 2001; Huberman \& Halka, 2001; Coughenour \& Saad, 2004; Victor, Perlin, \& Mastella, 2013; Silveira, Vieira, \& Costa, 2014; Bai \& Qin, 2015; Narayan, Zhang, \& Zheng, 2015; Tayeh, Bino, Ghunmi, \& Tayem, 2015). However, as pointed out by Anderson et al. (2016), the number of studies that analyzed the implications of commonality in liquidity is surprisingly small.

The studies conducted in Brazil documented the existence of commonality in liquidity in specifically selected periods of time (Victor et al., 2013; Silveira et al., 2014; Bai \& Qin, 2015). However, these studies did not seek to identify the implications of commonality for investors, a theme which is scarce both nationally and internationally. In addition, the Brazilian stock market has favorable conditions for the existence of high commonality, due to the low liquidity and high volatility of the market.

Therefore, an important question for the study of commonality in the Brazilian stock market is whether investors are compensated for dealing with commonality in the portfolios management. As suggested by Chordia et al. (2000), investors must be compensated for holding assets that are more sensitive to market liquidity variations.

The empirical evidence in the international studies by Acharya and Pedersen (2005), Lee (2011) and Hagströmer, Hansson, and Nilsson (2013) indicated that the risk premium for commonality in the US market is nearly zero. However, Anderson et al. (2016) demonstrated a significant positive premium for commonality in liquidity in the US market after controlling for liquidity.

Because of such differences between theoretical and empirical evidence about commonality in liquidity, and due to characteristics of emerging markets and to the existence of commonality in liquidity risk, which may affect firms, regulators and, mainly, investors, this paper introduces the following research problem:

- Is commonality in liquidity a priced risk factor in the Brazilian stock market? 
In Brazil, the studies about commonality in liquidity are recent (Victor et al., 2013; Silveira et al., 2014; Bai \& Qin, 2015). At first, this study aimed to document - by using the measure of Amihud (2002) as a proxy for liquidity - the existence of commonality in liquidity in the Brazilian stock market. Then, we sought to verify the monthly risk premium value for commonality in liquidity and, lastly, whether commonality is a priced risk factor and how exposed it is to the other risk factors.

In Brazilian studies (Victor et al., 2013; Silveira et al., 2014), the samples were only the stocks on the Bovespa index, that is, the most traded shares in the stock market. Our study used all the stocks traded on Bolsa, Brasil e Balcão - B3, selected on a few criteria (presented in section 3.1), leading to a study about the importance of commonality for the stock market in general.

In addition, if commonality in liquidity constitutes a non-diversifiable priced risk source, it is expected that the more sensitive an asset is to market shocks, the greater must be its expected return (Chordia et al., 2000; Anderson et al., 2016; Foran et al., 2015; Tayeh et al., 2015). In this sense, its implications are an important factor for many market participants, because understanding the consequences of liquidity covariation will help investors bear this risk more efficiently (Coughenour \& Saad, 2004).

Then, due to the low liquidity of the Brazilian stock market, we expect to find high commonality for the traded stocks, because commonality is the risk that a security becomes more illiquid when the market in general becomes more illiquid (Anderson et al., 2016). Besides, when analyzing its temporal aspect, we may observe whether this phenomenon is durable and also observe the implications of commonality for investors (demanding greater return for more sensitive assets), regulators (market crisis risk due to systematic variations in liquidity) and firms, since commonality negatively influences the value invested by firms (Qian et al., 2014).

Therefore, using the approach used by Qian et al. (2014) and Anderson et al. (2016), this study intends to complement and feed the national literature on commonality in liquidity, by investigating whether commonality in liquidity is priced, and by investigating its relations with stock returns in the Brazilian stock market.

\section{COMMONALITY IN LIQUIDITY: THEORETICAL BACKGROUND AND ITS IMPLICATIONS}

The main focus of the literature on market microstructure has been to study assets individually (Chordia et al., 2000). In this sense, the micro- 
structure models, based on inventory risk ${ }^{2}$, argue that the negotiation process is a matter of combining buy and sell orders, to be organized by market makers, who have a prominent position in market microstructure models (O'Hara, 1995). In addition, although the traditional paradigms do not picture the systematic effect of liquidity, it is possible to notice the effects of inventory risk and asymmetric information on commonality in liquidity (Chordia et al., 2000).

Although the studies in financial literature discuss liquidity risk in markets, this line of research has little connection with the risk of commonality in liquidity. While the investigation of co-movements of systematic liquidity and individual asset returns is named liquidity risk, $\operatorname{cov}\left(R_{i}, L_{m}\right)$, commonality in liquidity risk is defined as co-movements of systematic liquidity and individual asset liquidity, $\operatorname{cov}\left(L_{i}, L_{m}\right)$ (Anderson et al., 2016).

The funding constraint model of Brunnermeier and Pedersen (2009) explains the different situations regarding market liquidity, such as its sudden reduction, the commonality of stocks, its relation with volatility and, lastly, flight to liquidity. In turn, the liquidity-adjusted capital asset pricing model (LCAPM) of Acharya and Pedersen (2005) demonstrates theoretically that the risk of commonality influences the expected return.

Although a systematic liquidity component is consistent with the financial theory in terms of implications, up to the early 21 st century, few studies presented empirical evidence of commonality in liquidity (Chordia et al., 2000; Brockman \& Chung, 2002).

Chordia et al. (2000), Huberman and Halka (2001), and Hasbrouck and Seppi (2001) were the first to present evidence of commonality in liquidity in the US market. The pioneer study of Chordia et al. (2000) identified significant liquidity co-movements in the US market, indicating that the stock liquidity variation is determined by firm-specific systematic factors.

According to analyzed studies, such liquidity systematic variation is of great importance for investors, because, being one among other evidences, it implies a non-diversifiable risk source (Chordia et al., 2000; Brockman \& Chung, 2002; Narayan et al., 2015), it has an impact on the smooth working of the market (Syamala, Reddy, \& Goyal, 2014), it has time variations (Pukthuanthong-Le \& Visaltanachoti, 2009; Victor et al., 2013), and a seasonal effect (Kempf \& Maston, 2008).

Inventory risk is the cost that market makers have to deal with while their positions are open, that is, when they buy more than they sell or vice-versa. 
In the financial literature, there are few studies about commonality in liquidity covering the Brazilian stock market (Victor et al., 2013; Silveira et al., 2014; Bai \& Qin, 2015). Victor et al. (2013) analyzed data of 30 stocks traded on B3, between 2010 and 2012, and argued that commonality in liquidity is not constant and goes through variations throughout the day on which they are caused, mainly, by the impact of information. Then, by trying to adjust the position due to new information, investors go into trading, which, in turn, raises the individual stocks trading volume in the same period of time (Victor et al., 2013). These results were ratified by Silveira et al. (2014), who also found the existence of market liquidity co-movements in the Brazilian stock market.

There are different practical implications of commonality for traders, investors and regulators. One question is whether shocks in trading costs constitute a source of non-diversifiable priced risk (Chordia et al., 2000) or whether they may constitute a risk, because if liquidity shocks cannot be diversified, the sensitivity of an individual asset to such shocks could induce the market to demand a higher average return.

In this sense, common factors in liquidity seem to suggest that liquidity shocks are applied systematically to all investors and are transmitted across investors and/or stocks, causing broad market effects (Fernando, 2003). Then, a higher expected return would certainly be necessary for stocks with higher trading costs; however, such higher expected return could be an increment demanded from stocks with higher sensitivities to broad liquidity shocks.

Another important question both for participants and market regulators is whether changes in liquidity provision affect commonality and its relation with excess of returns (Galariotis \& Giouvris, 2009). Then, liquidity covariation may have implications for the market such as a demand for additional expected returns of stocks with higher sensitivities to broad liquidity shocks (Chordia et al., 2000).

For regulators and banks, understanding the effects of commonality is highly important, because such liquidity shocks may cause broad market effects that may impact its smooth working, leading to financial crises or stock market crashes (Syamala et al., 2014).

This way, commonality in liquidity is associated with market imperfections, where stocks with higher commonality in liquidity are more illiquid than other stocks, when the market in general becomes illiquid. In this sense, if the external funding of firms with higher commonality is more costly or more sensitive to market conditions than that of other firms, then 
these firms should invest less to reduce the adverse selection cost and/or preserve financial slacks for bad economic states (Qian et al., 2014).

Finally, the variability of commonality in liquidity may also influence policy-making. Having found that, in the Brazilian stock market, commonality in liquidity is higher at the beginning and at the end of the day, the creation of more aggressive circuit-breaker rules in such periods may minimize a chain reaction for systematic liquidity (Victor et al., 2013).

\subsection{Research hypothesis}

As per the content of item 2, our research hypothesis is associated with the implications of commonality in liquidity for investors. Knowing that the difference in market structures leads to broad differences in the characteristics of asset liquidity, this investigation and the supply of evidence about systematic liquidity pricing in the Brazilian stock market will be able to evaluate whether the differences of market structures and those of the characteristics of asset liquidity affect the findings and conclusions about the relation between systematic liquidity and stock returns, which have been documented mainly in the US market (Anderson et al., 2016; Foran et al., 2015).

Thus, this study presents information about the relation between commonality in liquidity and asset pricing. Note that liquidity may be priced as a characteristic or as a systematic risk factor (Foran et al., 2015). Therefore, by noting commonality in the Brazilian stock market, it is expected that stocks that are more sensitive to market liquidity variations offer a higher expected return as a compensation for their risk and also induce investors to hold such assets (Chordia et al., 2000; Anderson et al., 2016; Foran et al., 2015; Tayeh et al., 2015). In this sense, we come to the following research hypothesis:

- H1: Commonality is priced and has a positive relation with returns in the Brazilian stock market.

\section{METHODOLOGICAL PROCEDURES}

\subsection{Sample}

The sample of this study was composed of firms with stocks listed on B3, from January 2007 to December 2015. This time frame was chosen 
for comprising different moments in the stock market, such as financial crises, which may directly influence market liquidity (Chordia, Sarkar, \& Subrahmanyam, 2005).

The data of this research were collected from the Thomson Reuters ${ }^{\circledR}$ database and also from the B3 and the Securities and Exchange Commission (Comissão de Valores Mobiliários - CVM). In addition, to form the sample, three criteria had to be respected: 1 . we used the most liquid stock of each firm, based on the negotiability index; 2 . we selected stocks that were traded at least for 15 days in every month of the years analyzed; and 3. we selected the stocks whose trading price was over BRL 1.00, since low-value stocks tend to experience more return oscillations (Chordia et al., 2000). Moreover, B3 no longer allows trading stocks under BRL 1.00, because they are more volatile and easier to manipulate.

\subsection{Econometric model}

\subsubsection{Measuring commonality in liquidity}

To analyze commonality in the Brazilian stock market, we used the model proposed by Qian et al. (2014), in which the commonality in liquidity measure is obtained by $\mathrm{R}^{2}$, through a two-stage estimation method. First, we obtained the liquidity innovation measures, through the residuals from an autoregressive model for each stock (i), using daily observations of liquidity within each year $t$, as in Equation 1.

$$
L i q_{i, d, t}=\alpha_{0}+\alpha_{1} L i q_{i, d-1, t}+\sum_{w=1}^{4} \alpha_{2 i, d, t} D_{w}+\alpha_{3} H_{o l} l_{i, d, t}+u_{i, d, t}
$$

in which $L i q_{i, d, t}$ and $L i q_{i, d-1, t}$ are the illiquidity measure of Amihud (2002) on days $d$ and $d-1$ of year $t$, respectively. The measure of Amihud (2002) was obtained by $L i q_{i, d, t}=-\ln \left(1+\frac{\mid \text { ret }_{i, d, t} \mid}{v o l_{i, d, t}}\right)$, in which $\mid$ ret $_{i, d, t} \mid$ is the absolute daily return for stock $i$, on day $d$ of year $t$, and $v o l_{i, d, t}$ is the daily financial volume for stock $i$, on day $d$ of year $t$. The variable $D_{w}$ is a dummy for the days of the week, from Monday through Thursday, and $\mathrm{Hol}_{i, d, t}$ is a dummy variable for the holidays; these two latter variables were included to eliminate seasonal variation in liquidity (Chordia et al., 2005; Qian et al., 2014).

From the residual results of Equation 1, we obtained the commonality in liquidity measure, $\mathrm{R}^{2}$, through the regression model, as shown in Equation 2: 


$$
\hat{u}_{i, d, t}=\beta_{0 i, t}+\beta_{1 i, t} \hat{u}_{m, d, t}+\beta_{2 i, t} \hat{u}_{m, d+1, t}+\beta_{3 i, t} \hat{u}_{m, d-1, t}+e_{i, d, t}
$$

in which $\hat{u}_{m, d, t}, \hat{u}_{m_{, d}+1, t}$ and $\hat{u}_{m_{, d}-1, t}$ are market liquidity innovation measures value-weighted on December 31 of the previous year of $\hat{u}_{i, d, t}, \hat{u}_{i, d+1, t}, \hat{u}_{i, d-1, t}$ (obtained from Equation 1) over days $d, d+1$ and $d-1$ in year $t$, respectively.

Then, for each month, with the daily liquidity innovation of the market and of individual stocks, we obtained the value of monthly commonality for each of the stocks of the analyzed sample, through the $\mathrm{R}^{2}$ obtained from Equation 2. In addition, market commonality in liquidity was obtained by the individual commonalities' average.

At last, because $\mathrm{R}^{2}$ ranges from zero to one, we used the logarithmic transformation in the measure of $\mathrm{R}^{2}$, to use such value in the time-series regressions, as in Equation 3.

$$
\text { Commonality }_{i, m, t}=\ln \left(\frac{R_{i, m, t}^{2}}{\left(1-R_{i, m, t}^{2}\right)}\right)
$$

in which Commonality ${ }_{i, m, t}$ is the individual commonality in liquidity of stock $i$ in month $m$ of year $t$, after the logarithmic transformation to be used in the time-series regressions.

\subsubsection{Analyzing the risk of commonality in portfolios}

Commonality in liquidity constitutes a source of non-diversifiable risk (Chordia et al., 2000). In this sense, if priced, investors will demand a higher return for dealing with assets that have greater commonality in liquidity.

For this reason, we created portfolios based on illiquidity, calculated by the measure of Amihud (2002), and on commonality, calculated by the commonality measure $\left(\mathrm{R}^{2}\right)$ obtained from Equation 3, as suggested by Anderson et al. (2016). The analysis of commonality in portfolios may make changes in liquidity co-movements more evident, because the use of portfolios may eliminate great part of the firm-specific variation (Chordia et al., 2000).

Then, in June of each year, stocks were primarily ordered by their degree of illiquidity and, by using their median value, stocks were divided into two groups: low and high, that is, groups of stocks with low and high liquidity, respectively. Still in this very month, stocks were ordered by their degree of commonality risk and distributed in quintiles: the first quintile corresponded to the stocks with the lowest commonality, whereas the last quintile repre- 
sented the stocks with the highest commonality. In the same month, after the two previous orderings, ten portfolios were constructed, formed by the intersection of the two liquidity groups and the five commonalities in liquidity groups.

Then, for each month, we calculated the return of each stock, through its natural logarithm. To calculate the monthly return of each of the ten portfolios, we weighted the stock's market value on the portfolio's market value, the returns of the stocks that compose the portfolios. This way, we obtained a premium for investors to deal with the risk of commonality in liquidity, by the difference between the average monthly returns of the groups with the highest and lowest commonality.

In addition, to verify whether commonality in liquidity constitutes a priced risk factor in the Brazilian stock market, we used the two-stage regression process - cross-sectional and time series - of Fama and Macbeth (1973); in the first stage, the returns of the ten portfolios constructed on liquidity and commonality were regressed on market, size, B/M, momentum, liquidity and commonality as risk factors, through time-series regression, to obtain the beta coefficients of the explanatory factors, as in Equation 4.

$$
\begin{aligned}
& \left(R_{i, t}\right)-R_{f, t}=\alpha_{i}+\beta_{i, m k t}\left[\left(R_{m, t}\right)-R_{f, t}\right]+\beta_{i, S M B}\left(\operatorname{SMB}_{t}\right)+\beta_{i, \text { HML }}\left(H M L_{t}\right)+ \\
& \beta_{i, \text { MOM }}\left(\operatorname{MOM}_{t}\right)+\beta_{i, \text { LIQ }}\left(\mathrm{LIQ}_{t}\right)+\beta_{i, \text { СOM }}\left(\mathrm{PCom}_{t}\right)+\varepsilon_{i, t}
\end{aligned}
$$

in which $\left(R_{i, t}\right)$ is the monthly return of the portfolios constructed on commonality and liquidity; $\mathrm{R}_{\mathrm{f}}$ is the risk-free rate; $\left(R_{m}\right)-R_{f}$, is the market risk premium in month $t$; SMB is the size risk premium in month $t$; HML is the book-to-market risk premium in month $t$; $M O M$ is the momentum risk premium in month $t$, LIQ is the liquidity risk premium in month $t$, PCom is the commonality in liquidity risk premium in month $t$.

In the second phase, a single cross-sectional regression was estimated for the average excess returns on the betas estimated in Equation 4. This way, the verification of the validity of the risk factors will be estimated through Equation 5:

$$
\left(\bar{R}_{i}\right)-\bar{R}_{f}=\lambda_{0}+\lambda_{1} \hat{\beta}_{i, m k t}+\lambda_{2} \hat{\beta}_{i, \text { smb }}+\lambda_{3} \hat{\beta}_{i, h m l}+\lambda_{4} \hat{\beta}_{i, \text { mom }}+\lambda_{5} \hat{\beta}_{i, \text { liq }}+\lambda_{6} \hat{\beta}_{i, \text { pcom }}+\varepsilon_{i}
$$

in which $\left(\bar{R}_{i}\right)-\bar{R}_{f}$ is the average excess return in the analyzed period, $\beta$ are the parameters estimated in the first phase and $\lambda_{1}, \lambda_{2}, \lambda_{3}, \lambda_{4}, \lambda_{5}, \lambda_{6}$ are the 
coefficients of the following risk factors: market, size, BM, momentum, liquidity and commonality, respectively. Then, on the estimation of the second phase, if the coefficient $\lambda_{6}$ is significant and positive, this suggests that commonality in liquidity constitutes a priced risk factor.

Note that, for the cross-sectional regression estimation, the standard errors of the risk factor must be corrected, considering that the independent variables in Equation 5 are regressors estimated in Equation 4. In this sense, we used the correction of Shanken (1992), which corrects the underestimated standard error as in Fama and Macbeth's (1973). Thus, the standard errors will be corrected by the factor $\left(1+\hat{\lambda}^{\prime} \hat{\Sigma}_{f}^{-1} \hat{\lambda}\right)^{-1}$, in which $\hat{\Sigma}_{f}$ is the covariance matrix of market, size, $\mathrm{B} / \mathrm{M}$, momentum, liquidity and commonality factors, and $\hat{\lambda}$, is the estimated parameters matrix.

Finally, as in Anderson et al. (2016) and Fama and French (2015), the premium for commonality in liquidity was regressed on the other risk factors, commonly documented in the financial literature: market, size, book-to-market, momentum and liquidity. This analysis was conducted with the purpose of verifying the exposition of commonality premium to the other risk factors, that is, if commonality is absorbed by such factors. In this sense, commonality was checked for redundancy, that is, if commonality is present in the other risk factors. To this end, we analyzed the significance of the intercept of the regression models and the risk factor coefficients of each model. On this analysis, if the intercept is not significant and one of the risk factor coefficients is significant, this indicates that the average return for commonality is captured by the exposition of commonality to the other risk factors.

Then, the monthly premiums of the high-low strategy for commonality in liquidity were regressed on the risk factors, with an annual adjustment of the portfolios, as in Equation 6.

$$
P \_C o m=\alpha+\beta_{i}[\text { Market }]+s_{i}(S M B)+h_{i}(H M L)+m_{i}(M o m)+l_{i}(L I Q)+\varepsilon_{i}
$$

in which $P_{-}$Com is the monthly premium of the high-low strategy for commonality in liquidity; Market is the market risk premium; $S M B$ is the size risk premium; HML is the book-to-market risk premium; Mom is the momentum risk premium and LIQ is the liquidity risk premium. Risk factors were obtained according to the methodology presented by Machado and Medeiros (2011). 


\section{RESULTS}

\subsection{Descriptive analysis of the sample}

Upon the application of exclusion criteria, data from 1,315 stocks were collected, which, on average, meant 146 stocks ( $39.22 \%$ of the population) per year (Figure 4.1.1). When compared with the sample of international studies, this is a reduced number of analyzed stocks, which is one of the problems with the Brazilian stock market, due to the small number of listed firms (Machado \& Medeiros, 2011).

Figure 4.1.1 shows that, over the years, there has been a reduction in the number of firms listed on B3, possibly due to the low price of stocks and the high cost to remain listed. However, we believe that the sample has a satisfactory size compared to the studies of Victor et al. (2013), who analyzed the data of 30 stocks, and Silveira et al. (2014), who analyzed the data of 69 stocks traded on B3.

(Figure 4.1.1)

POPULATION AND SAMPLE

\begin{tabular}{cccc}
\hline Year & Population & Sample & \% of population \\
\hline 2007 & 404 & 89 & 22.03 \\
\hline 2008 & 393 & 129 & 32.82 \\
\hline 2009 & 385 & 123 & 31.95 \\
\hline 2010 & 381 & 147 & 38.58 \\
\hline 2011 & 373 & 157 & 42.09 \\
\hline 2012 & 364 & 162 & 44.50 \\
\hline 2013 & 363 & 168 & 46.28 \\
\hline 2014 & 363 & 171 & 47.11 \\
\hline 2015 & 359 & 169 & 47.07 \\
\hline Average & 376 & 146 & 39.22 \\
\hline
\end{tabular}

Source: Elaborated by the authors.

\subsection{Evidence of commonality in liquidity}

Figure 4.2.1 shows for each year the number of stocks, average value, minimum and maximum values for commonality in liquidity. From 2007 to 
2015, the number of stocks selected to construct the sample increased, possibly due to the raise in the number of participants in the Brazilian stock market, to the increase of market liquidity, as well as to the increase of the number of trades on B3 in the period.

(Figure 4.2.1)

AVERAGE RESULTS FOR COMMONALITY IN THE ANALYZED PERIOD

\begin{tabular}{cccccc}
\hline Year & Number of stocks & Average & Minimum & Maximum & Standard deviation \\
\hline 2007 & 89 & 0.200 & 0.003 & 0.998 & 0.172 \\
\hline 2008 & 129 & 0.189 & 0.001 & 0.910 & 0.151 \\
\hline 2009 & 123 & 0.194 & 0.001 & 0.998 & 0.185 \\
\hline 2010 & 147 & 0.197 & 0.000 & 0.894 & 0.151 \\
\hline 2011 & 157 & 0.174 & 0.002 & 0.997 & 0.148 \\
\hline 2012 & 162 & 0.167 & 0.000 & 0.998 & 0.152 \\
\hline 2013 & 168 & 0.177 & 0.001 & 0.999 & 0.156 \\
\hline 2014 & 171 & 0.204 & 0.000 & 0.996 & 0.159 \\
\hline 2015 & 169 & 0.176 & 0.001 & 0.997 & 0.143 \\
\hline General average & 146 & 0.186 & 0.001 & 0.976 & 0.157 \\
\hline
\end{tabular}

Source: Elaborated by the authors.

In addition, Figure 4.2.1 shows that the commonality found for the Brazilian stock market, represented by the average value, is greater than that found in the international literature (Chordia et al. (2000) found a value of 0.09 for commonality in the US market), but close to that found in the Brazilian market (Silveira et al. (2014) found a value of 0.220 for commonality).

Besides, noting the values of commonality in liquidity for the Brazilian stock market (Figure 4.2.1), we see that, during the subprime crisis period, from 2007 to 2010, there was an increase in commonality values, with an average value close to 0.20 and a maximum value of 0.998 . In this sense, based on the presented results, it may be said that commonality in liquidity is a phenomenon present in the Brazilian stock market.

In addition, we aimed to analyze the existence of size effect for commonality in liquidity, that is, greater or smaller sensitivity of stocks to systematic variations in liquidity, depending on the size of the firm, as documented in the international literature (Chordia et al., 2000; Pukthuanthong-Le \& Visaltanachoti, 2009; Syamala et al., 2014). 
To verify the existence of the size effect on commonality, we classified the selected stocks in quartiles (from the $1^{\text {st }}$ to the $3^{\text {rd }}$ quartile) on their market value. After classifying them in quartiles, we analyzed the value of the annual average commonality calculated for each quartile, seeking to verify a growth in the value of commonality as the market value of the sample rose across the quartiles. The results for the size effect analysis are presented in Figure 4.2.2.

(Figure 4.2.2)

AVERAGE VALUE FOR COMMONALITY ACROSS QUARTILES

\begin{tabular}{cccc}
\hline \multirow{2}{*}{ Year } & \multicolumn{3}{c}{ Commonality } \\
\cline { 2 - 4 } & First quartile & Second quartile & Third quartile \\
\hline 2007 & 0.193 & 0.195 & 0.202 \\
\hline 2008 & 0.194 & 0.193 & 0.188 \\
\hline 2009 & 0.195 & 0.193 & 0.189 \\
\hline 2010 & 0.193 & 0.192 & 0.193 \\
\hline 2011 & 0.184 & 0.177 & 0.172 \\
\hline 2012 & 0.161 & 0.159 & 0.162 \\
\hline 2013 & 0.170 & 0.168 & 0.171 \\
\hline 2014 & 0.191 & 0.192 & 0.200 \\
\hline 2015 & 0.178 & 0.175 & 0.172 \\
\hline
\end{tabular}

Source: Elaborated by the authors.

According to Figure 4.2.2, it is not possible to note the existence of size effect based on the annual averages of commonalities for each quartile, that is, as firm size increases, commonality in liquidity does not grow. One possible conclusion to be drawn from such result is a greater sensitivity of smaller-sized stocks to commonality, as found by Tayeh et al. (2015), since, in the results shown in Figure 4.2.2, we notice an increased average value of commonality for smaller-sized stocks in periods of crisis (subprime crisis and political crisis).

One possible reason for the size effect not to be present could be the influence of extreme values for some stocks within the quartiles; however, the average was winsorized at $10 \%$ for each quartile and the results did not change, which, therefore, signals that size effect does not exist in commonality in liquidity. 


\subsection{Analyzing commonality in portfolios}

\subsubsection{Description of the portfolios}

To verify whether investors will achieve a greater return for dealing with assets with higher commonality in liquidity, this study aimed to identify the existence of a premium for dealing with commonality in the portfolios. To this end, ten portfolios were constructed based on the intersection of two liquidity groups (Low and High) and five groups on commonality quintiles. Figure 4.3.1.1 shows the yearly number of stocks in each portfolio in the analyzed period.

(Figure 4.3.1.1)

AVERAGE NUMBER OF STOCKS PER PORTFOLIO PER YEAR

\begin{tabular}{cccccccccc}
\hline Portfolio/year & 2007 & 2008 & 2009 & 2010 & 2011 & 2012 & 2013 & 2014 & 2015 \\
\hline LL/LC & 8 & 10 & 12 & 14 & 15 & 18 & 19 & 17 & 19 \\
\hline LL/2C & 8 & 10 & 13 & 15 & 15 & 14 & 17 & 17 & 15 \\
\hline LL/3C & 7 & 9 & 11 & 14 & 13 & 16 & 16 & 17 & 17 \\
\hline $\mathrm{LL} / 4 C$ & 8 & 10 & 11 & 13 & 14 & 14 & 15 & 16 & 17 \\
\hline $\mathrm{LL} / \mathrm{HC}$ & 7 & 11 & 12 & 15 & 18 & 15 & 16 & 17 & 18 \\
\hline $\mathrm{HL} / \mathrm{LC}$ & 7 & 10 & 12 & 15 & 15 & 14 & 14 & 16 & 15 \\
\hline $\mathrm{HL} / 2 \mathrm{C}$ & 8 & 11 & 10 & 13 & 16 & 16 & 16 & 17 & 19 \\
\hline $\mathrm{HL} / 3 \mathrm{C}$ & 8 & 10 & 13 & 15 & 16 & 14 & 17 & 17 & 17 \\
\hline $\mathrm{HL} / 4 \mathrm{C} C$ & 7 & 10 & 13 & 15 & 16 & 16 & 18 & 17 & 17 \\
\hline $\mathrm{HL} / \mathrm{HC}$ & 8 & 10 & 12 & 14 & 13 & 16 & 17 & 16 & 16 \\
\hline
\end{tabular}

Source: Elaborated by the authors.

Figure 4.3.1.2 shows the market value and return of the portfolios per year. Therein, we see that the high liquidity stocks have a higher market value when compared to lower liquidity stocks, which suggests a positive relation between size and liquidity and, possibly, the use of stocks' market value as a possible proxy for liquidity, ratifying the findings of Machado and Medeiros (2011).

In addition, Figure 4.3.1.2 shows the average return per year of each portfolio, based on the 96 monthly data on return (July 2007 to June 2015). 
The average return per year ranged from $-0.362 \%$ (portfolio LL/LC) to $0.095 \%$ (portfolio LL/3C).

\section{(Figure 4.3.1.2)}

\section{MARKET VALUE AND AVERAGE RETURN OF PORTFOLIOS PER YEAR (THOUSANDS)}

\begin{tabular}{|c|c|c|c|c|c|c|c|c|c|}
\hline $\begin{array}{c}\text { Portfolio/ } \\
\text { year }\end{array}$ & 2007 & 2008 & 2009 & 2010 & 2011 & 2012 & 2013 & 2014 & 2015 \\
\hline LL/LC & 33,259 & 15,629 & 21,800 & 21,264 & 23,087 & 34,134 & 32,552 & 18,579 & 20,891 \\
\hline LL/2C & 30,122 & 18,559 & 24,580 & 47,522 & 20,292 & 23,293 & 30,711 & 23,678 & 13,835 \\
\hline LL/3C & 36,867 & 18,545 & 15,963 & 21,620 & 34,260 & 32,256 & 28,239 & 30,273 & 21,947 \\
\hline $\mathrm{LL} / 4 \mathrm{C}$ & 35,498 & 16,030 & 11,955 & 17,326 & 27,076 & 27,485 & 25,381 & 21,273 & 22,719 \\
\hline LL/HC & 23,083 & 48,596 & 16,573 & 177,731 & 108,572 & 71,973 & 64,255 & 80,175 & 83,601 \\
\hline HL/LC & 324,793 & 274,654 & 218,426 & 266,856 & 305,653 & 274,208 & 208,286 & 360,404 & 371,428 \\
\hline $\mathrm{HL} / 2 \mathrm{C}$ & 276,651 & 300,932 & 232,031 & 322,741 & 389,622 & 373,858 & 356,403 & 415,802 & 413,304 \\
\hline $\mathrm{HL} / 3 \mathrm{C}$ & 220,605 & 303,227 & 284,314 & 380,836 & 295,874 & 358,611 & 385,735 & 300,974 & 479,054 \\
\hline $\mathrm{HL} / 4 \mathrm{C}$ & 177,661 & 255,741 & 237,459 & 395,533 & 409,728 & 332,639 & 428,312 & 397,112 & 295,139 \\
\hline $\mathrm{HL} / \mathrm{HC}$ & 342,043 & 200,165 & 284,863 & 257,291 & 266,023 & 384,801 & 407,208 & 393,519 & 348,836 \\
\hline \multicolumn{10}{|c|}{ Average return of portfolios per year } \\
\hline $\begin{array}{c}\text { Portfolio/ } \\
\text { year }\end{array}$ & 2007 & 2008 & 2009 & 2010 & 2011 & 2012 & 2013 & 2014 & 2015 \\
\hline LL/LC & -0.362 & -0.080 & -0.333 & 0.028 & -0.011 & 0.028 & -0.012 & -0.040 & 0.004 \\
\hline $\mathrm{LL} / 2 \mathrm{C}$ & -0.051 & -0.075 & 0.086 & 0.025 & 0.001 & 0.013 & -0.004 & -0.036 & -0.052 \\
\hline $\mathrm{LL} / 3 \mathrm{C}$ & -0.042 & -0.081 & 0.095 & 0.029 & 0.016 & 0.040 & -0.016 & 0.000 & -0.037 \\
\hline $\mathrm{LL} / 4 \mathrm{C}$ & 0.015 & -0.049 & 0.079 & 0.025 & 0.026 & 0.018 & -0.014 & -0.021 & -0.031 \\
\hline $\mathrm{LL} / \mathrm{HC}$ & -0.010 & -0.063 & 0.089 & 0.007 & -0.008 & 0.015 & -0.006 & -0.005 & 0.031 \\
\hline $\mathrm{HL} / \mathrm{LC}$ & 0.025 & -0.026 & 0.052 & -0.003 & -0.010 & 0.011 & 0.003 & -0.001 & 0.007 \\
\hline $\mathrm{HL} / 2 \mathrm{C}$ & 0.021 & -0.057 & 0.040 & -0.004 & -0.020 & 0.005 & -0.004 & 0.005 & 0.005 \\
\hline $\mathrm{HL} / 3 \mathrm{C}$ & 0.019 & -0.043 & 0.049 & -0.004 & -0.018 & 0.024 & 0.015 & -0.004 & -0.001 \\
\hline $\mathrm{HL} / 4 \mathrm{C}$ & 0.037 & -0.028 & 0.035 & 0.004 & -0.003 & 0.020 & 0.001 & -0.004 & 0.012 \\
\hline $\mathrm{HL} / \mathrm{HC}$ & 0.027 & -0.032 & 0.028 & 0.037 & 0.005 & 0.015 & -0.007 & -0.001 & 0.018 \\
\hline
\end{tabular}

Source: Elaborated by the authors. 
Regarding commonality, the portfolios formed by high-commonality stocks were expected to have returns superior to those of portfolios formed by low-commonality stocks. This pattern is not common to all years when portfolio returns are compared. However, on average, the returns of portfolios containing high-commonality stocks were superior to those of low-commonality portfolios, indicating the existence of a premium for commonality in liquidity in the Brazilian stock market, in the analyzed period.

\subsubsection{Analyzing risk factors}

After constructing the portfolios, we found the monthly risk premium for investors to deal with commonality in liquidity. Figure 4.3.2.1 shows the monthly premium for market, size, $\mathrm{B} / \mathrm{M}$, momentum, liquidity and commonality as risk factors, according to the used proxies. The monthly premium results from the monthly average of the 96 months selected (from July 2007 to June 2015). Besides monthly premium, Figure 4.3.2.1 shows the standard deviation, $t$-test, $\mathrm{p}$-value as well as minimum and maximum values.

(Figure 4.3.2.1)

RISK FACTOR MONTHLY PREMIUMS

\begin{tabular}{lcccccc}
\multicolumn{1}{c}{ Factors } & Average (\%) & Standard deviation & t-Test & P-value & Minimum & Maximum \\
\hline Market & 0.397 & 0.059 & 0.658 & 0.512 & -0.255 & 0.121 \\
\hline Size & -0.227 & 0.041 & -0.538 & 0.592 & -0.065 & 0.266 \\
\hline Book-to-market & -2.087 & 0.053 & -3.817 & 0.000 & -0.111 & 0.272 \\
\hline Momentum & 1.240 & 0.054 & 2.241 & 0.027 & -0.279 & 0.300 \\
\hline Liquidity & -1.220 & 0.045 & -2.606 & 0.011 & -0.170 & 0.120 \\
\hline Commonality & 4.165 & 0.282 & 1.448 & 0.151 & -0.108 & 2.541 \\
\hline
\end{tabular}

Source: Elaborated by the authors

We note that the market monthly premium for the analyzed period was $0.397 \%$ per month, however, not statistically significant. Although not significant, market premium value is very inferior to that of Machado and Medeiros (2011), who found a premium of $3.09 \%$. A possible explanation for such difference is the effect of international financial crises occurred in the analyzed period (2007-2015), as well the effect of the small growth of the Brazilian economy, followed by the raise of benchmark interest rates. 
As for size, the results obtained in Figure 4.3.2.1 show that the difference between the average returns of the small and big portfolios was negative and not statistically significant, indicating that there is no premium for size factor in the Brazilian stock market, corroborating the findings of Machado and Medeiros (2011).

We also found no evidence of the $\mathrm{B} / \mathrm{M}$ factor in the Brazilian stock market, as suggested in Figure 4.3.2.1, since the difference between the average return of the portfolios formed by high- $\mathrm{B} / \mathrm{M}$ firms and the returns of the portfolios formed by low-B/M stocks was negative. Corroborating the results of Machado and Medeiros (2011), this research also found a negative premium for $\mathrm{B} / \mathrm{M}$ of $2.087 \%$ per month, statistically significant at $1 \%$.

As to momentum, we found a premium of $1.24 \%$ per month, significant at 5\%, ratifying the findings of Machado and Medeiros (2011), who found a return of $1.7 \%$ per month for momentum, therefore, confirming the existence of a momentum effect in the Brazilian stock market.

The illiquidity variable of Amihud (2002) was used to obtain the liquidity premium and the results in Figure 4.3.2.1 show a statistically significant negative premium of 1.22 . The evidence of a statistically significant liquidity effect corroborates the findings of Machado and Medeiros (2011), who found a statistically significant positive premium $(0.766 \%)$ for liquidity in the Brazilian stock market.

As to commonality, we found a premium of $4.165 \%$ per month, which, although not statistically significant, ratifies the findings of Lee (2011), who found a positive - not statistically significant - premium (close to zero) for developed markets. However, this result is contrary to that obtained by Anderson et al. (2016), who found a commonality premium between $0.218 \%$ and $0.438 \%$, depending on the liquidity measure to be used, for the US market.

\subsubsection{Analyzing commonality risk factor}

Finally, we aimed to analyze the relation of commonality in liquidity with the other risk factors. Figure 4.3.3.1 shows the correlation matrix for all analyzed factors. According to Figure 4.3.3.1, the correlations between the factors are low, except between liquidity and market factors, which was moderate (0.546), and between size and $\mathrm{B} / \mathrm{M}$ factors (0.511).

The correlation matrix also shows a positive and significant correlation between size and liquidity factors, ratifying the findings of Figure 4.3.1.2, in which market value could be a proxy for liquidity, corroborating the findings of Machado and Medeiros (2011). 


\section{(Figure 4.3.3.1)}

CORRELATION MATRIX OF RISK FACTORS AND COMMONALITY

\begin{tabular}{lcccccc}
\hline & Market & Size & BM & Momentum & Liquidity & Commonality \\
\hline Market & 1 & & & & & \\
\hline Size & $-0.239^{\star \star}$ & 1 & & & & \\
\hline BM & -0.001 & $0.511^{\star \star \star}$ & 1 & & & \\
\hline Momentum & $-0.297^{\star \star \star}$ & 0.049 & 0.011 & 1 & & \\
\hline Liquidity & $0.546^{\star \star \star}$ & $0.279^{\star \star \star}$ & 0.075 & -0.116 & 1 & \\
\hline Commonality & -0.068 & 0.045 & 0.058 & -0.069 & -0.184 & 1 \\
\hline
\end{tabular}

***,** significant at $1 \%$ and $5 \%$ respectively.

Source: Elaborated by the authors

In addition, the commonality factor showed no significant correlation with the market factor $(-0.068)$. According to Figure 4.3.3.1, the liquidity and commonality factors had a negative and statistically non-significant correlation (-0.184), suggesting that these factors behave differently, since they have a negative correlation.

With the aim of verifying if commonality in liquidity constitutes a priced risk factor in the Brazilian stock market, the two-stage regression process was used with standard error corrected by the Shanken (1992) method, as in equations 4 and 5 . The objective of the two-stage regression is to verify the significance of the coefficients estimated in the second stage and, in special, the significance of the coefficient for the commonality factor, in that, being statistically significant, it suggests that the commonality factor is priced in the Brazilian stock market. The results are shown in Figure 4.3.3.2.

\section{(Figure 4.3.3.2)}

TWO-STAGE REGRESSION COEFFICIENTS

\begin{tabular}{cccccc}
\hline & Panel A: Stage 1 & \multicolumn{3}{c}{ Panel B: Stage 2 } \\
\hline & Coef. & t-statistics & & Coef. & $\begin{array}{c}\text { Shanken } \\
\text { t-statistics }\end{array}$ \\
\hline Intercept & -0.002 & -1.782 & Intercept & -0.003 & -0.652 \\
\hline$\beta_{i, m k t}$ & 1.084 & 26.622 & $\lambda_{1}$ & 0.014 & 1.906 \\
\hline$\beta_{i, \text { smb }}$ & 0.286 & 7.249 & $\lambda_{2}$ & -0.081 & -12.544 \\
\hline
\end{tabular}




\section{(Figure 4.3.3.2 (conclusion)) \\ TWO-STAGE REGRESSION COEFFICIENTS}

\begin{tabular}{|c|c|c|c|c|c|}
\hline \multicolumn{3}{|c|}{ Panel A: Stage 1} & \multicolumn{3}{|c|}{ Panel B: Stage 2} \\
\hline & Coef. & t-statistics & & Coef. & $\begin{array}{l}\text { Shanken } \\
\text { t-statistics }\end{array}$ \\
\hline$\beta_{\text {,hml }}$ & -0.052 & -1.612 & $\lambda_{3}$ & -0.009 & -1.112 \\
\hline$\beta_{\text {imom }}$ & 0.222 & 7.803 & $\lambda_{4}$ & 0.008 & 0.835 \\
\hline$\beta_{i, i, q_{q}}$ & 0.127 & 1.064 & $\lambda_{5}$ & -0.011 & -5.937 \\
\hline$\beta_{i, p c o m}$ & -0.182 & -0.951 & $\lambda_{6}$ & 0.043 & 8.705 \\
\hline
\end{tabular}

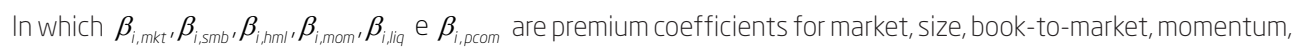
liquidity and commonality. Moreover, $\lambda_{1}, \lambda_{2}, \lambda_{3}, \lambda_{4}, \lambda_{5}$ and $\lambda_{5}$ are coefficients for the parameters $\hat{\beta}_{i, m \in t}, \hat{\beta}_{i, s m b}, \hat{\beta}_{i, h m^{\prime \prime \prime}}$ $\hat{\beta}_{i, \text { mom }}, \hat{\beta}_{i, l,}$ e $\hat{\beta}_{i, \text { com }}$ obtained in the first phase.

The standard error was corrected by the factor of Shanken $\left(1+\hat{\lambda} \hat{\Sigma}_{f}^{-1} \hat{\lambda}\right)^{-1}$, in which $\hat{\Sigma}_{f^{\prime}}$ is the covariance matrix of MKT, SMB, HML, MOM, LIQ and PCOM factors, and $\hat{\lambda}$, is the estimated parameters matrix.

Source: Elaborated by the authors.

According to the results shown in Figure 4.3.3.2, the commonality factor constitutes a priced risk factor in the Brazilian stock market, having a positive and statistically significant coefficient at $1 \%$. Therefore, although we note no statistically significant premium for commonality in liquidity in the Brazilian stock market (Figure 4.3.2.1.), in the economic sense, commonality in liquidity positively influences stock returns. Thus, based on these results, Hypothesis 1 - that the commonality factor is priced and has a positive relation with returns - cannot be rejected.

In addition, identifying the pricing of commonality in liquidity in the Brazilian stock market corroborates the argument of Chordia et al. (2000), that commonality constitutes a non-diversifiable priced risk factor (for it is a systematic effect), for which investors must demand a higher return to deal with the risk of commonality in liquidity.

According to the results of Figure 4.3.2.1, there is an economically positive premium for the strategy based on commonality, even though there is no statistical significance. This result may derive from the liquidity measure used $^{3}$, and from the process of portfolio formation, because, according to

\footnotetext{
Tests were conducted on two liquidity measures: traded volume and turnover. In both cases, commonality yielded - economically - a positive premium, but with no statistical significance.
} 
evidences of Anderson et al. (2016), depending on the liquidity measure used, we note a higher premium that is both economically and statistically significant for commonality in liquidity.

In addition, to better understand the commonality risk premium and its exposition to the other risk factors commonly documented in the literature, we followed the strategy adopted by Fama and French (2015) and Anderson et al. (2016). The study of such exposition of the commonality factor to the other risk factors is meant to verify if the commonality factor is not redundant, that is, if it is not absorbed by the other risk factors. Figure 4.3.3.3 presents the results obtained.

First, we regressed the commonality risk premium on the CAPM model only to add the other risk factors next, up to the formation of the five-factor risk pricing model (market, size, book-to-market, momentum, and liquidity). The initial results showed that, in the three- and four-factor CAPM models, no factor was significant to explain the commonality factor, indicating that this is a unique factor, which may, for example, be used in an asset-pricing model.

Finally, the five-factor pricing model was used. Thus, the monthly premiums of commonality in liquidity were used as an independent variable and market, size, $\mathrm{B} / \mathrm{M}$, momentum and liquidity were risk factors used as explanatory variables, as in Equation 6.

\section{(Figure 4.3.3.3)}

\section{EXPOSITION OF THE COMMONALITY PREMIUM} TO THE OTHER RISK FACTORS

\begin{tabular}{cccccccccc}
\multicolumn{6}{c}{$P_{-}$Com $=\alpha+\beta_{i}[$ Market $]+s_{i}(S M B)+h_{i}(H M L)+m_{i}($ Mom $)+l_{i}(L I Q)+\varepsilon_{i}$} \\
\hline Model & Intercept & $\beta_{i}$ & $s_{i}$ & $h_{i}$ & $m_{i}$ & $l_{i}$ & F statistic & Adj. $\mathrm{R}^{2}$ \\
\hline 5 factors & 0.029 & 0.497 & 1.048 & 0.012 & -0.412 & $-1.803^{\text {** }}$ & 1.134 & 0.007 \\
\hline
\end{tabular}

${ }^{* * *}$ significant at $1 \%$.

The results of Figure 4.3.3.3 show that the commonality risk factor is partly explained by the liquidity risk factor, despite its low explanatory power, since the liquidity factor was statistically significant at $1 \%$. This result may be associated with the findings of Acharya and Pedersen (2005), who demonstrated that three types of liquidity risk influence asset returns. 
In addition, this result contradicts the findings of Anderson et al. (2016), who, when analyzing the exposition of commonality premium to the other risk factors, by using the effective spread liquidity measure, verified that the commonality factor was redundant when exposed to the market, size and momentum factors. However, the redundancy of the commonality factor to the other risk factors is believed to be associated with the liquidity measure used to obtain commonality, because, as per the evidences of Anderson et al. (2016), when the price impact measure is used, the commonality factor is no longer redundant.

\section{CONCLUSION}

This study aimed to verify if commonality in liquidity is priced in the Brazilian stock market. To this end, we obtained the value of commonality in liquidity for the analyzed period and the monthly premium for a strategy based on commonality in liquidity. In addition, we investigated whether commonality constitutes a priced risk factor in the Brazilian stock market, and we analyzed if the commonality factor is absorbed by the other risk factors.

The results demonstrated that commonality for the Brazilian stock market had, throughout 108 months, an average value of 0.186 , superior to that found in the international literature, and it may be considered reasonable due to the huge variety of variables that may influence the stock market which cannot be used in one single statistical model. Moreover, commonality in liquidity was found to be a priced risk factor not absorbed by the other risk factors noted in the literature; for this reason, the hypothesis of this study - that commonality is priced and has a positive relation with returns in the Brazilian stock market - cannot be rejected.

As far as implications for investors are concerned, we identified an increase in the transaction cost in periods of market decline, due to the increase of commonality. Although we noted a positive premium for the investment strategy based on commonality in liquidity, its average value was not found to be statistically significant. In addition, one contribution is the economic evidence that commonality is priced, and its effect is greater on smallersized firms.

Finally, in terms of practical implications, we may conclude that investors must pay more attention to the commonality risk in their portfolios, as they process orders, and, to the moment of trading, due to the increase of transaction costs of stocks that have more sensitivities to commonality in liquidity. 


\section{A COMUNALIDADE NA LIQUIDEZ É UM FATOR DE RISCO PRECIFICÁVEL?}

\section{RESUMO}

Objetivo: Analisar se a comunalidade na liquidez é precificada e sua relação com o retorno acionário no mercado acionário brasileiro.

Originalidade/valor: Por causa da incipiência, na literatura financeira brasileira, do tema comunalidade na liquidez, este artigo proporciona o desenvolvimento do conhecimento acerca do efeito da comunalidade na liquidez para o investidor, investigando se uma estratégia de investimento em ativos mais sensíveis a variações sistemáticas da liquidez é atrativa para os investidores, condizente com a trade off risco-retorno.

Design/metodologia/abordagem: Para identificar o efeito da comunalidade para o investidor, optou-se pela utilização de carteiras. Adotando como amostra as empresas listadas na B3, foram desenvolvidas regressões em série de tempo, no período de janeiro de 2007 a dezembro de 2015.

Resultados: Verificou-se que a comunalidade é um fenômeno presente no mercado acionário brasileiro e que os seus maiores valores se concentraram nos períodos das crises financeiras internacionais. Ademais, com a utilização de carteiras, observou-se um prêmio de $4,165 \%$ ao mês para a comunalidade na liquidez, apesar de não significativo estatisticamente. Por fim, constatou-se que a comunalidade na liquidez constitui um fator de risco precificável e, ao expô-lo aos demais fatores de risco, verificou-se que o fator de risco liquidez conseguiu parcialmente capturá-lo.

\section{PALAVRAS-CHAVE}

Comunalidade. Investimento. Liquidez. Risco. Retorno.

\section{REFERENCES}

Acharya, V. V., \& Pedersen, L. (2005). H. Asset pricing with liquidity risk. Journal of Financial Economics, 77, 375-410. doi:10.1016/j.jfineco.2004.06.007 
Amihud, Y. (2002). Illiquidity and stock returns: cross-section and timeseries effects. Journal of Financial Markets, 5(1), 31-56.

Anderson, R. G., Binner, J., Hagströmer, B., \& Nilsson, B. (2016). Does commonality in illiquidity command a risk premium? [Working Paper], doi:10.2139/ssrn.2281459

Bai, M., \& Qin, Y. (2015). Commonality in liquidity in emerging markets: Another supply-side explanation. International Review of Economics and Finance, 39, 90-106. doi:10.1016/j.iref.2015.06.005

Brockman, P., \& Chung, D. Y. (2002). Commonality in liquidity: evidence from an order-driven market structure. The Journal of Financial Research, XXV(4), 521-539. doi:10.1111/1475-6803.00035

Brunnermeier, M. K., \& Pedersen, L. H. (2009). Market liquidity and funding liquidity. The Review of Financial Studies, 22(6), 2201-2238. doi:10.1093/ rfs/hhn098

Chordia, T., Roll, R., \& Subrahmanyam, A. (2000). Commonality in liquidity. Journal of Financial Economics, 56, 3-28. doi:10.1016/S0304-405X(99)00057-4

Chordia, T., Sarkar, A., \& Subrahmanyam, A. (2005). An empirical analysis of stock and bond market liquidity. The Review of Financial Studies, 18(1), 85-129. doi:10.1093/rfs/hhi010

Coughenour, J. F., \& Saad, M. M. (2004). Common market makers and commonality in liquidity. Journal of Financial Economics, 73, 37-69. doi:10.1016/j. jfineco.2003.05.006

Fama, E. F., \& French, K. R. (2015). A five-factor asset pricing model. Journal of Financial Economics, 116(1), 1-22. doi:10.1016/j.jfineco.2014.10.010

Fama, E. F., \& Macbeth, J. D. (1973). Risk, return and equilibrium: Empirical tests. Journal of Political Economy, 81 (3), 607-636.

Fernando, C. S. (2003). Commonality in liquidity: Transmission of liquidity shocks across investors and securities. Journal of Financial Intermediation, 12, 233-254. doi:10.1016/S1042-9573(03)00041-X

Foran, J., Hutchinson, M. C., \& O’Sullivan, N. (2015). Liquidity commonality and pricing in UK equities. Research in International Business and Finance, 34, 281-293. doi:10.1016/j.ribaf.2015.02.006

Galariotis, E. C., \& Giouvris, E. L. (2009). Systematic liquidity and excess returns: Evidence from the London stock exchange. Review of Accounting and Finance, 8(3), 279-307. doi:10.1108/14757700910980868

Hagströmer, B., Hansson, B., \& Nilsson, B. (2013). The components of the liquidity premium: An empirical analysis of US stocks 1927-2010. Journal of Banking \& Finance, 37(11), 4476-447. doi:10.1016/j.jbankfin.2013.01.029 
Hasbrouck, J., \& Seppi, D. J. (2001). Common factors in prices, order flows, and liquidity. Journal of Financial Economics, 59(3), 283-411. doi:10.1016/ S0304-405X(00)00091-X

Huberman, G., \& Halka, D. (2001). Systematic liquidity. The Journal of Financial Research XXIV(2), 161-178. doi:10.1111/j.1475-6803.2001.tb00 763.x

Kempf, A., \& Mayston, D. (2008). Liquidity commonality beyond best prices. The Journal of Financial Research, XXXI(1), 25-40. doi:10.1111/j. 1475-6803.2008.00230.x

Lee, K. (2011). The world price of liquidity risk. Journal of Financial Economics, 99, 136-161. doi:10.1016/j.jfineco.2010.08.003

Machado, M. A. V., \& Medeiros, O. R. (2011). Asset pricing model and the liquidity effect: Empirical evidence in the Brazilian stock market. Brazilian Review of Finance, 9(3), 383-412. Retrieved from http://bibliotecadigital. fgv.br/ojs/index.php/rbfin/article/view/2862

Mayordomo, S., Rodriguez-Moreno, M., \& Peña, J. I. (2014). Liquidity commonalities in the corporate CDS Market around the 2007-2012 financial crisis. International Review of Economics and Finance, 31, 171-192. doi:10.10 16/j.iref.2014.02.001

Narayan, P. K., Zhang, Z., \& Zheng, X. (2015). Some hypothesis on commonality in liquidity: New evidence from the Chinese stock market. Emerging Markets Finance and Trade, 51(5), 915-944. doi:10.1080/1540496X.2015. 1061799

O’Hara, M. (1995). Market microstructure theory. Cambridge, MA: Blackwell.

Pukthuanthong-Le, K., \& Visaltanachoti, N. (2009). Commonality in liquidity: Evidence from the stock exchange of Thailand. Pacific-Basin Finance Journal, 17, 80-99. doi:10.1016/j.pacfin.2007.12.004

Qian, X., Tam, L. H. K., \& Zhang, B. (2014). Systematic liquidity and the funding liquidity hypothesis. Journal of Banking \& Finance, 45, 304-320. doi:10.1016/j.jbankfin.2013.08.020

Sadka, R (2011). Liquidity risk and accounting information. Journal of Accounting and Economics, 52, 144-152. doi:10.1016/j.jacceco.2011.08.007

Silveira, V. G., Vieira, K. M., \& Costa, A. (2014). Comunalidade na liquidez: Um estudo intraday para as ações do índice Bovespa. Revista Estudos do CEPE, 39, 139-156. doi:10.17058/cepe.v0i39.4031

Shanken, J. (1992). On the estimation of beta-pricing models. The Review of Financial Studies, 5(1), 1-33. 
Syamala, S. R., Reddy, V. N., \& Goyal, A. (2014). Commonality in liquidity: An empirical examination of emerging order-driven equity and derivatives market. Journal of International Financial Markets, Institutions \& Money, 33, 317-334.

Tayeh, M., Bino, A., Ghunmi, D. A., \& Tayem, G. (2015). Liquidity commonality in an emerging market: Evidence from Amman stock exchange. International Journal of Economics and Finance, 7(2), 203-213. doi:10.5539/ ijef.v7n2p203

Victor, F. G., Perlin, M. S., \& Mastella, M. (2013). Commonalities in liquidity: Evidence and intraday patterns in the Brazilian market. Brazilian Review of Finance, 11(3), 375-398. Retrieved from http://bibliotecadigital.fgv.br/ ojs/index.php/rbfin/article/view/7434

\section{AUTHOR NOTES}

Cláudio P. Silva Júnior, doctor in Administration by the Graduate Program in Administration, Federal University of Paraíba (UFPB); Márcio A. V. Machado, doctor in Administration by the Graduate Program in Administration, University of Brasília (UnB).

Cláudio P. Silva Júnior is now assistant professor at the Management Department of Federal University of Paraíba (UFPB); Márcio A. V. Machado is now associate professor at the Management Department of Federal University of Paraíba (UFPB).

Correspondence concerning this article should be addressed to Márcio A. V. Machado, Cidade Universitária, campus I, Castelo Branco, João Pessoa, Paraíba, Brazil, CEP 58.051-900.

E-mail: mavmachado@hotmail.com

\section{EDITORIAL BOARD}

Editors-in-chief Janette Brunstein

Silvia Marcia Russi De Domênico

Associated Editor

Flavio Luiz de Moraes Barboza

Technical Support

Vitória Batista Santos Silva

\section{EDITORIAL PRODUCTION}

Publishing Coordination

Jéssica Dametta

Editorial Intern

Paula Di Sessa Vavlis

Language Editor

Daniel de Almeida Leão
Layout Designer

Emap

Graphic Designer

Libro 